JURNAL PIWULANG, Vol. I No. 1 September 2018, 33-53

\title{
Reinterpretasi Jihad PDM \& PCNU Kota Madiun sebagai Upaya Membendung Laju Radikalisme Agama
}

\author{
Khoirul Mudawinun Nisa' \\ STAI Madiun \\ mudawinunnisa@yahoo.coi.id
}

\begin{abstract}
ABSTRAK
Islam adalah agama rahmat yang diturunkan diantaranya untuk mengajarkan perilaku yang santun. Namun demikian, citra Islam sebagai agama yang penuh rahmat kadang tercoreng dengan adanya kelompok yang mengatasnamakan Islam, tetapi berperilaku tidak sejalan dengan ajaran Islam. Hal tersebut bermula dari penafsiran meraka yang salah terhadap makna jihad yang mereka tafsirkan dengan makna qital. Di Kota Madiun, tantangan ini berupaya diredam oleh dua organisasi Muslim terbesar, yakni Muhammadiyah dan Nahdlatul Ulama. konsep jihad yang diusung oleh Muhammadiyah dan NU hampir serupa karena keduanya memiliki sikap moderat dengan menggunakan triologi: Tawasuth/i'tidal, tawazun, dan tasammuh. Kontruksi sosial konsep jihad kedua ormas ini berangkat dari pemahaman Al-Qur'an dan Hadis yang disandingkan dengan keadaan sosio-kultural pada zamannya.
\end{abstract}

Kata Kunci: Konsep Jihad, Radikalisme Agama, Muhammadiyah \& NU

\section{A. Pendahuluan}

Pada abad 21 ini, salah satu tantangan terbesar yang dihadapi oleh organisasi keagamaan yang berhaluan moderat seperti Nahdatul Ulama (NU) dan Muhammadiyah ialah gerakan atau menguatnya ideologi transnasional dalam kehidupan sosial-agama ideologi transnasional terekpresikan dalam bentuk religious exstrimism (Global Islamism, Hindu Evangelism). ${ }^{1}$

Peran ormas Islam di Indonesia sudah membawa banyak perubahan dan juga banyak bermunculan gerakan-gerakan yang radikal

\footnotetext{
${ }^{1}$ Menurut Karen Amstrong, gerakan radikalisme ataupin fundamentalisme tidak hanya terdapat pada agama munities saja, ada juga fundamentalisme Budha, Hindu dan bahkan Kong $\mathrm{Hu} \mathrm{Cu}$, yang sama-sama menolak butir-bitir nilai budaya liberal, saling berperang atas nama agama (Tuhan) dan berusaha membawa hal-hal yang sakral kedalam urusan politik dan Negara. Lihat Karen Amstrong,Berperang Demi Tuhan, terj.Sutrisno Wahono dkk, (Jakarta Bandung: Kerjasama Serambi dengan Mizan, 2001), x
} 
dalam organisasi. Selama beberapa dekade yang lalu banyak kalangan yang meng-claim bahwa Ikwanul Muslimin dan HTI, Wahhabi telah mempengaruhi umat Islam setempat dengan pahamnnya yang ekstrim. Walaupun memiliki perspektif yang berbeda, termasuk dalam beberapa detail pemahaman keagamaan namun tujuan gerakan yang dibangun yakni tidak jauh berbeda yaitu formalisasi Islam. Untuk mencapai tujuan ini kelompok-kelompok garis keras menggunakan segala cara, bahkan yang bertentangan dengan ajaran Islam itu sendiri. Prinsip yang lazim menjadi pegangan para ulama ahlussunnah waljamaah menegaskan bahwa tujuan tidak bisa membenarkan cara (al-ghayah la tubaari alwashilah atau man kana amruhu ma'rufan fal-yakun bi ma'rufin) artinya cara tidak akan menjadi baik karena tujuan baik, atau siapapun yang mempunyai tujuan baik hendaknya dilakukan dengan cara-cara yang baik pula. Tujuan baik, jika diusahakan dengan cara-cara buruk, tentu akan menodai kebaikan itu sendiri dan bertentangan.

Kelompok-kelompok garis keras menganggap setiap Muslim lain yang berbeda dari mereka sebagai jurang Islami, atau bahkan kafir dan murtad, maka mereka melakukan infiltrasi kemasjid-masjid, lembagalembaga pendidikan, instansi-instansi pemerintah maupun swasta, dan ormas-ormas Islam moderat, terutama Muhammadiyah dan NU, untuk mengubahnya menjadi keras dan kaku juga. Kelompok ini menganggap Muhammadiyah dan NU sebagai penghalang utama pencapaian agenda politik mereka, karena keduanya sudah lama memperjuangkan substansi nilai-nilai Islam, bukan formalisasi Islam dalam bentuk negara maupun penerapan syariat sebagai hukum positif. ${ }^{2}$.

Di Kota Madiun, tantangan ini berupaya diredam oleh dua organisasi Muslim terbesar, yakni Muhammadiyah dan Nahdlatul Ulama. Kedua organisasi ini dikelompokkan ke dalam versi moderatisme Islam karena ketidaksetujuannya dengan sikap dan pandangan keagamaan kalangan garis keras yang menggunakan cara-cara kekerasan. Kedua organisasi ini juga sejak awal tidak setuju dengan isu laten yang diusung oleh kalangan Muslim garis keras. Bagi keduanya, bentuk Negara Kesatuan Republik Indonesia (NKRI) dengan Pancasila sebagai asas ideologisnya, UUD 1945 sebagai basis konstitusinya, dan Bhinneka Tunggal Ika sebagai semboyannya, dianggap sudah cukup mengakomodasi elemen-elemen substantif ajaran Islam moderat yang bervisi rahmatan lil alamin.

2 Abdurrahman Wahid, Musuh dalam Selimut. Dalam Buku Ilusi negara Islam : ekspansi gerakan Islam transnasional di Indonesia. (Jakarta : TheWahid Institute, 2009)., h. 22 
Fenomena keberhasilan dakwah PDM dan PCNU Kota Madiun dalam menafsirkan kembali konsep jihad, menjadikan Islam tetap eksis dan digandrungi banyak masyarakat. Dengan beragam dimensi kehidupan tradisional maupun modern yang berkembang di masyarakat, melatarbelakangi diajukannya judul ini untuk diteliti. Tulisan ini berupaya mendiskripsikan dan menganalisis bahasan tentang reinterpretasi jihad dalam membendung laju radikalisme agama oleh PDM dan PCNU Kota Madiun.

\section{B. Kerangka Dasar Teori}

Peter L. Berger dan Thomas Luchman ${ }^{3}$ memahami dunia kehidupan (life world) selalu dalam proses dialektik antara the self (individu) dan dunia sosio kultural. Proses dialektik itu mencakup tiga momen simultan, yaitu eksternalisasi (penyesuaian diri dengan dunia sosio kultural sebagai produk manusia), objektivasi (interaksi dengan dunia intersubjektif yang dilembagakan atau mengalami institusionalisasi), dan internalisasi (individu mengidentifikasi dengan lembaga-lembaga sosial atau organisasi sosial tempat individu menjadi anggotanya).

Tahap eksternalisasi dan objektivasi merupakan pembentukan masyarakat yang disebut sebagai sosialisasi primer, yaitu momen di mana seseorang berusaha mendapatkan dan membangun tempatnya dalam masyarakat. Dalam kedua tahap ini (eksternalisasi dan objektivasi) seseorang memandang masyarakat sebagai realitas objektif (man in society). Sedangkan dalam tahap internalisasi, seseorang membutuhkan pranata sosial (social order), dan agar pranata itu dapat dipertahankan dan dilanjutkan, maka haruslah ada pembenaran terhadap pranata tersebut, tetapi pembenaran itu dibuat juga oleh manusia sendiri melalui proses legitimasi yang disebut objektivasi sekunder. Pranata sosial merupakan hal yang objektif, independen dan tak tertolak yang dimiliki oleh individu secara subjektif. Ketiga momen dialektik itu mengandung fenomena-fenomena sosial yang saling bersintesa dan memunculkan suatu konstruksi sosial atau realitas sosial, yang dilihat dari asal mulanya merupakan hasil kreasi dan interaksi subjektif.

Mengikuti konstruksi sosial Berger, realitas sosial jihad menjadi terperlihara dalam teks-teks agama bagi kelompok Islam radikal. Doktrin agama pun akhirnya berhasil melegitimasi wacana "jihad" tersebut, terlebih ketika agama dijadikan sebagai ideologi negara. Walhasil, bagi Islam radikal, "jihad" menjadi sebuah realitas sosial yang tak

\footnotetext{
${ }^{3}$ Peter L. Berger \& Thomas Lukhmann. Tafsir Sosial atas Kenyataan. (Jakarta: LP3ES, 1190), 1.
} 
terbantahkan, bahkan mustahil untuk dihilangkan. Demikian pula wacana yang mengiringinya.

Tabel 1:

Kontruksi Sosial

\begin{tabular}{|c|c|}
\hline $\begin{array}{c}\text { Siklus } \\
\text { Kontruksi }\end{array}$ & Keterangan \\
\hline Eksternalisasi & $\begin{array}{l}\text { - Proses dimana individu memiliki suatu gagasan yang } \\
\text { kemudian diinteraksikan kepada orang lain dalam bentuk } \\
\text { saling mempengaruhi. } \\
\text { - Pengetahuan yang dimiliki individu yang kemudian } \\
\text { disampaikan kepada individu yang lainnya }\end{array}$ \\
\hline Objektivitas & $\begin{array}{l}\text { - Gagasan yang dimiliki dari berbagai individu hingga } \\
\text { mencapai suatu kesepakatan dan menciptakan } \\
\text { pengetahuan baru yaitu pengetahuan massal (kolektif) } \\
\text { - Merupakan proses norma secara kolektif } \\
\text { - Proses pelembagaan (institusional) }\end{array}$ \\
\hline Internalisasi & $\begin{array}{l}\text { - Proses sosialisasi pengetahuan bersama (kolektif), dan } \\
\text { gagasan yang telah disepakati sebelumnya kepada } \\
\text { masyarakat, supaya individu didalam masyarakat semakin } \\
\text { memahami pengetahuan kolektif tersebut } \\
\text { - Norma dipahami oleh individu dan mendarah daging } \\
\text { dalam jiwa individu } \\
\text { - Realitas objektif (masyarakat) bersemayam dalam } \\
\text { kesadaran subjektif (individu) }\end{array}$ \\
\hline
\end{tabular}

\section{1) Konsep Jihad: Tinjauan Al Qur'an dan Hadits}

Secara etimologis, kata "jihad" adalah bentuk masdar dari "jahada" yang bermakna al-taqah (kekuatan), sebagaimana ungkapan ijhad jahdak (kerahkan kekuatanmu). Dikatakan juga, al-jahd (dengan fathah) bermakna kesulitan (al-mashaqqah), sementara al-juhd (dengan dammah) bermakna kekuatan (al-taqah). ${ }^{4}$ Makna kamus "jihad" menyatakan bahwa "perang" bukanlah makna satu-satunya, ada varian makna yang bisa dicakup sebagaimana makna dasarnya: keseriusan; kesungguhan; pengerahan segenap daya kemampuan.

Menurut al-Raghib sebagaimana dikutip al-Husayni, makna hakiki jihad adalah istifragh al-wus'i wa al-juhd, yakni pengerahan daya kemampuan untuk menolak tiga hal; memerangi musuh yang nyata, syetan dan hawa nafsu. ${ }^{5}$

\footnotetext{
${ }^{4}$ Ibn Manzur, Lisan al-'Arab (Kairo: Dar al-Ma'arif, t.t.), I : 708 dan 710

${ }^{5}$ M. Quraish Shihab, Wawasan al-Qur'an (Jakarta: Mizan, 1998), 506.
} 
Menurut pembacaan tradisional terhadap teks, konsep jihad dalam al-Qur'an melewati empat gradasi; pertama, pada awalnya Nabi diperintahkan untuk mensosialisasikan Islam secara damai dengan menghindari konfrontasi langsung dengan Kaum Kafir (al-Hijr (15): 94) Kedua, Nabi diperintahkan untuk melakukan konfrontasi dengan media argumentasi yang "ahsan" sebagaimana diekspresikan dalam surat alNahl (16): 125 dan al-'Ankabut (29): 46. Ketiga, Nabi diizinkan untuk melakukan konfrontasi fisik, karena pengusiran yang dilakukan kelompok kafir (al-Hajj (22): 39, al-Baqarah (2): 193, al-Tawbah (9): 5. Keempat, gradasi terakhir, yakni turunnya perintah untuk melakukan perlawanan terhadap nonmuslin dalam kondisi apapun (al-Baqarah (2): 244). Perlawanan ini dianggap terus berlangsung sebagai hal yang bersifat imperatif, karena tanpanya superioritas Islam dan inferioritas nonmuslim tidak akan mewujud. Pemahaman masyarakat muslim ataupun nonmuslim terhadap konsep al-Qur'an tentang jihad yang hanya pada gradasi keempat tersebut menimbulkan implikasi pemahaman bahwa memperjuangkan Islam adalah dengan cara kekerasan dan fisik.

Untuk menunjukkan kekayaan makna jihad, al-Qur'an sendiri telah membedakan antara konsep ini dengan konsep qital (interaksi bersenjata). ${ }^{6}$ Kata "al-qital" diulang penyebutannya sebanyak 6 kali yang semuanya bermakna interaksi bersenjata, dalam surat al-Baqarah (2): 216, 246, al-Nisa' (4): 77, al-Anfal (8): 65, al-Ahzab (33): 25, Muhammad (47): 25. Sementara itu jihad dalam pengertian perang, hanyalah salah satu varian

Berdasar beberapa paparan hadis, banyak teks hadis tentang jihad yang bisa dipahami secara radik dan fisik jikalau mengandalkan pemahaman yang bersifat literal. Sementara pemahaman yang sebenarnya terhadap hadis tidak sesederhana itu, akan tetapi melibatkan pengecekan terhadap sanad (transmisi hadis) dan matan. Dari sisi sanad misalnya, dituntut adanya kualitas kelimuan dan moralitas perawi serta ketersambungan antar perawi sanad. Dari sisi matan, disyaratkan bahwa matan hadis tidak bertentantangan dengan teks-teks lain, khususnya al-Qur'an. Seandainya, sanad dan matan sebuah hadis dinilai otentik, fiqh al-hadith (pemahaman hadis dengan melibatkan sisi sosio-historis), serta kontekstualisasi makna hadis mutlak diperlukan. ${ }^{7}$

\footnotetext{
${ }^{6}$ Alwi shihab, Islam Inklusif (Jakarta: Mizan, 1998), 284.

7 Abid Rohmanu, "Kritik Teks dan Kekerasan Atas Nama Agama”, al-Adabiya, Vol. 2, No. 1 (Januari-Juni 2007), 82.
} 
JURNAL PIWULANG, Vol. I No. 1 September 2018, 33-53

\section{2) Radikalisme Agama: Ciri dan Faktor Penyebabnya}

Radikal berasal dari bahasa latin radix yang artinya akar. Dalam bahasa Inggris kata radical dapat bermakna ekstrim, menyeluruh, fanatik, revolusioner, ultra dan fundamental. ${ }^{8}$ Sedangkan radicalism artinya doktrin atau praktik penganut paham radikal atau paham ekstrim. ${ }^{9}$ Dalam Kamus Besar Bahasa Indonesia, radikalisme diartikan sebagai paham atau aliran yang menginginkan perubahan dengan cara keras atau drastis. ${ }^{10}$

Sementara Sartono Kartodirdjo mengartikan radikalisme sebagai gerakan sosial yang menolak secara menyeluruh tertib sosial yang sedang berlangsung dan ditandai oleh kejengkelan moral yang kuat untuk menentang dan bermusuhan dengan kaum yang memiliki hakhak istimewa dan yang berkuasa. ${ }^{11}$ Sedangkan dalam studi Ilmu Sosial, Radikalisme diartikan sebagai pandangan yang ingin melakukan perubahan yang mendasar sesuai dengan interpretasinya terhadap realitas social atau ideologi yang dianutnya. ${ }^{12}$ Dapat disimpulkan bahwa yang dimaksud dengan radikal bila dilihat dari pemahaman agama, dan yang kami maksud dalam penelitian ini adalah agama Islam, adalah gerakan yang berpandangan kolot dan sering menggunakan kekerasan dalam mengajarkan keyakinan mereka.

Kelompok radikal memiliki ciri-ciri antara lain; ${ }^{13}$ pertama sering mengklaim kebenaran tunggal dan menyesatkan kelompok lain yang tak sesuai dengan ideologinya. Kedua, radikalisme mempersulit agama Islam yang sejatinya samhah (ringan) dengan menganggap ibadah sunnah seakan-akan wajib dan makruh seakan-akan haram. Ketiga, kelompok radikal kebanyakan berlebihan dalam beragama yang tidak pada tempatnya. Keempat, kasar dalam berinteraksi, keras dalam berbicara dan emosional dalam berdakwah. Kelima, kelompok radikal mudah berburuk sangka kepada orang lain di luar golongannya. Keenam, mudah mengkafirkan orang lain yang berbeda pendapat.

\footnotetext{
8 A.S.Hornby, oxford Advenced, Dictionary of current English (UK: Oxford university press, 2000), 691.

9 Nuhrison M. Nuh, Faktor-Faktor Penyebab Munculnya Faham/ Gerakan Islam Radikal di Indonesi (HARMONI Jurnal Multikultural \& Multireligius, Vol VIII Juli-September 2009), 36.

10 Departemen Pendidikan dan Kebudayaan, Kamus Besar Bahasa Indonesia (Jakarta: Balai Pustaka, 1990 ), 354.

11 Sartono Kartodirdjo, Ratu Adil (Jakarta: Sinar Harapan, 1985), 38.

12 Ismail Hasani dan Bonar Tigor Naipospos, Radikalisme Agama di Jabodetabek \& Jawa Barat: Implikasinya terhadap Jaminan Kebebasan Beragama/Berkeyakinan (Jakarta: Pustaka Masyarakat Setara, 2010), 19.

13 Irwan Masduqi, Deradikalisasi Pendidikan Islam Berbasis Khazanah Pesantren (Jurnal Pendidikan Islam, No 2 Vol 1, 2012), 3.
} 
Dalam masalah sumber radikalisme, Azyumardi Azra berpendapat. Dikalangan Umat Islam radikalisme itu banyak bersumber dari : ${ }^{14}$

a. Pemahaman keagamaan yang literal, sepotong -sepotong terhadap ayat-ayat Al-Qur'an. pemahaman seperti itu hampir tidak Umumnya moderat, dan dan karena itu menjadi arus utama (maninstream) umat.

b. Bacaan yang salah terhadap sejarah umat Islam yang dikombinasikan dengan idealisasi berlebihan terhadapumat Islam pada masa tertentu. Ini terlihat dalam pandangan dan gerakan salafi, khususnya dalam spectrum sangat radikal seperti wahabiyah yang mncul disemenanjung Arabia pada akhir abad 18 awal sampai pada abad 19 dan terus merebak sampai sekarang ini.

c. Deprivasi politik, sosial dan ekonomi yang masih bertahan dalam masyarakat. Pada saat yang sama, disorientasi dan dislokasi sosial budaya, dan ekses globalisasi, dan semacamnya sekaligus merupakan tambahan faktor-faktor penting bagi kemunculan kelompok-kelompok radikal. Kelompok-kelompok sempalan tersebut tidak jarang mengambil bentuk kultus (cult) yang sangat eksklusif, tertutup dan berpusat pada seseorang yang dipandang kharismatik.

d. Masih berlanjutnya konflik sosial bernuansa intra dan antar agama dalam masa reformasi, sekali lagi, disebabkan berbagai faktor amat komplek. Pertama, berkaitan dengan euphoria kebebasan, dimana setiap orang atau kelompok merasa dapat mengekspresikan kebebasan dan kemauanya tanpa peduli dengan pihak-pihak lain. Dengan demikian terdapat gejala menurunya toleransi. Kedua, masih berlanjutnya fragmentasi politik dan sosial khususnya dikalangan elit politik, sosial, militer, yang terus mengimbas ke lapisan bawah (grassroot) dan menimbulkan konflik horizontal yang laten dan luas.

e. Melalui internet, selain menggunakan media kertas, kelompok radial juga memanfaatkan dunia maya untuk menyebarkan bukubuku dan informasi tentang jihad.

\footnotetext{
14 Azyumardi Azra, Akar Radikalisme Keagamaan Peran Aparat Negara, Pemimpin Agama dan Guru untuk Kerukunan Umat Beragama (Makalah dalam Workshop "Memperkuat Toleransi Melaluai Institusi Sekolah", yang diselenggarakan oleh The Habibie Center, 14 Mei 2011, di Hotel Aston Bogor), dan dikutip oleh Abdul Munip, Menangkal Rdikalisme di Sekolah (Jurnal Pendidikan Islam UIN Sunan Kalijaga Program Pasca Sarjana No 2 Vol 1, Desember 2012), 162.
} 
JURNAL PIWULANG, Vol. I No. 1 September 2018, 33-53

\section{Metode}

Metode yang digunakan dalam penelitian ini adalah metode penelitian kualitatif dengan pendekatan interaktif studi multi kasus, karena dilakukan dengan studi mendalam pada suatu kesatuan sistem dengan menghimpun data, kemudian mengambil maknanya, sehingga memperoleh gambaran secara lengkap tentang reinterpretasi jihad PDM dan PCNU Kota Madiun.

Dalam penelitian ini, peneliti menggunakan teori Kontruksi sosial Berger dan Luchman dimana individu dengan institusinya adalah sebuah dialektika yang terekspresi dalam tiga kategori, yaitu: pertama masyarakat sebagai produk individu; kedua, masyarakat sebagai realtias objektif; dan ketiga, individu adalah produk masyarakat atau sosial. Dialektika ini dimediasikan oleh pengetahuan yang didasarkan atas memori pengalaman di satu sisi dan oleh peranan yang diekspresikan oleh individu dalam orde sosial di sisi lain. ${ }^{15}$ Dalam hal ini, peneliti akan mencoba menggali konsepsi jihad dan dialektika kontruksi sosial yang diusung oleh PDM dan PCNU kota Madiun sebagai upaya membendung laju radikalisme agama. Hubungan antara akar radikalisme, strategi deradikalisasi dan tujuan deradikalisasi akan digambarkan sebagi berikut:

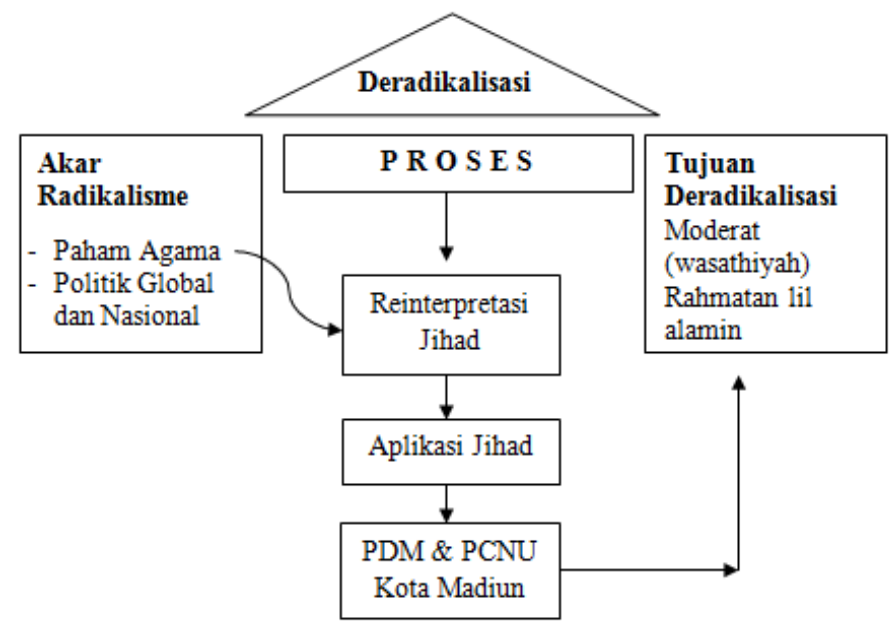

Subjek dan sumber data penelitian ini adalah "individu" pengurus PDM dan PCNU kota Madiun. Pemilihan informan dan subjek penelitian dilakukan berdasarkan arahan dari ketua pengurus. Tehnik ini digunakan dengan cara menjaring sebanyak mungkin informasi dari berbagai

${ }^{15}$ Lihat Water Malcoln, Modern Sosiological Theory (London: Sage Publications, 1994), 35. 
sumber sampai mengalami titik jenuh. ${ }^{16}$ Data dari penelitian ini adalah dokumen-dokumen terkait seperti profil kepengurusan, hasil bahsul masail, hasil tarjih, program kerja dan lain sebagainya.

Adapun metode yang digunakan untuk mengumpulkan data dengan observasi, wawancara mendalam (in-depth interview) dan dokumetasi. Data yang telah dikumpulkan dianalisis melalui tahapantahapan, yaitu reduksi data, penyajian data, pemeriksaan kesimpulan serta verifikasi data. Peneliti juga melakukan tiangulasi kepada informan dan konfirmasi data (konfirmabilitas) kepada subjek penelitian yang dianggap perlu. Hal ini sangat membantu peneliti akan validitas data yang peneliti olah setelah melakukan wawancara. Berikutnya adalah tahap penarikan kesimpulan, yaitu menarik kesimpulan dengan cara memberikan interpretasi terhadap data yang telah dianalisis pada tahap reduksi data (data reduction) dan sajian data (data display).

\section{Hasil Penelitian}

\section{1) Konsep Jihad PDM \& PCNU Kota Madiun}

Dalam pandangan Muhammadiyah jihad dimaknai dengan pengertian bekerja sepenuh hati. Makna itu sangat menarik karena jihad tidak dijelaskan dengan kata berperang, melainkan bekerja keras, bekerja cerdas, dan bekerja ikhlas. Ajaran jihad diejawantahkan dalam bentuk berkarya untuk memperbaiki kondisi bangsa. Ibarat jarum jam, Muhammadiyah terus bergerak guna melahirkan amal-amal sosial yang bermanfaat bagi umat. Dengan memahami ajaran agama sebagai praksis sosial (a faith with action), Muhammadiyah terus berkarya dengan mendirikan sekolah, rumah sakit, panti asuhan, serta lembaga perekonomian.

Secara lebih spesifik, Muhammadiyah melalui Lembaga Hikmah dan Kebijakan Publik (LHKP) senantiasa memberikan perhatian dan kepedulian untuk menjaga Indonesia sebagai sebuah bangsa besar yang berciri; pertama, berdaulat dan bermartabat, terbebas dari rongrongan atau tekanan kekuatan manapun, baik dari dalam maupun luar negeri. Kedua, menjunjung tinggi keadilan, demokrasi, dan hak asasi manusia. Ketiga, menjunjung tinggi nilai-nilai luhur, sebagaimana diajarkan agama dan Pancasila. Keempat, menghormati dan memberikan perlindungan sekaligus memperkokoh kerukunan di kalangan umat dengan keyakinan dan pandangan keagamaan yang

${ }^{16}$ Lexi J. Moleong, Metodologi Penelitian Kualitatif (Bandung : Remaja Rosdakarya, 1992), 165166 
berbeda. Kelima, memberikan tempat yang cukup bagi terwujudnya kehidupan dan sistem politik yang demokratis dan bermartabat. ${ }^{17}$

Melalui keputusan Muktamar ke-46, juga dikemukakan bahwa Muhammadiyah akan berperan dalam isu-isu strategis keummatan, kebangsaan, dan kemanusiaan universal. Isu kebangsaan meliputi kemiskinan, kepemimpinan keteladanan, komoditisasi agama, konservatisme agama, kemajemukan, dan gender. Masalah kebangsaan meliputi peluruhan visi dan karakter bangsa, korupsi, penegakan hukum, kesejahteraan pekerja, suksesi kepemimpinan nasional, reformasi birokrasi, dan persoalan agraria. Adapun masalah kemanusiaan universal terkait dengan krisis pangan dan energi, krisis ekonomi, krisis lingkungan hidup dan perubahan iklim, islamfobia, migrasi global, serta dialog agama dan peradaban. ${ }^{18}$

Konsep Jihad muhammadiyah dapat diselaraskan pada pemikiran Muhammadiyah dalam mengaplikasian perkembangan umat islam yaitu Konsep Jihad Pertama, mewujudkan Islam yang berkemajuan dan menyebarluaskan pencerahan. Dengan ini, Muhammadiyah melakukan peneguhan dan pengayaan makna tentang ajaran akidah, ibadah, dan akhlak kaum muslimin, sekaligus melakukan pembaruan dalam mu'amalat dunyawiyah yang membawa perkembangan hidup sepanjang kemauan ajaran Islam. Paham Islam yang berkemajuan semakin meneguhkan perspektif tentang tajdid yang mengandung makna pemurnian (purifikasi) dan pengembangan (dinamisasi) dalam gerakan Muhammadiyah, yang seluruhnya berpangkal dari gerakan kembali kepada Al-Quran dan As-Sunnah (al-ruju' ila al-Quran wa alSunnah) untuk menghadapi perkembangan zaman.

Menurut Haedar Nashir, maksud dari "ideologi Islam yang berkemajuan" adalah bahwa Muhammadiyah berupaya menampilkan corak Islam yang memadukan antara purifikasi dengan dinamisasi, dan bersifat moderat (wasatiyah) dalam meyakini, memahami, dan melaksanakan ajaran Islam. Muhammadiyah dengan watak ini berbeda dengan karakter gerakan-gerakan Islam lain yang cenderung ekstrem, baik yang bersifat radikal-fundamentalis ataupun radikal-liberal. Ideologi moderat ini bukanlah paham yang tidak jelas, lembek dan plinplan, karena Muhammadiyah dalam paham dan sikap keagamaannya memiliki prinsip yang tegas, lugas, dan kuat sebagaimana manhaj

17 Lihat Lampiran Laporan Pimpinan Pusat Muhammadiyah, "Laporan Lembaga Pimpinan Pusat Muhammadiyah Periode 2010-2015", diterbitkan oleh Pimpinan Pusat Muhammadiyah, 2015, hlm. 235.

18 Haedar Nashir, Dinamisasi Gerakan Muhammadiyah, Agenda Strategis Abad Kedua, (Yogyakarta: Suara Muhammadiyah, 2015), hlm. 70. 
gerakan Muhammadiyah. ${ }^{19}$ Ideologi dengan karakter moderat ini mengindikasikan bahwa Muhammadiyah berbeda dengan gerakan Islam radikal-liberal yang serba liberal dalam melakukan dekonstruksi atas ajaran Islam sehingga serba relatif; dan pada saat yang sama berbeda dengan gerakan radikal-fundamentalis semisal Salafi, Wahabi, Tarbiyah/al-Ikhwan al-Muslimun, Taliban, Jemaah Tabligh, Islam Jemaah, Jemaah Islamiyah, Hizbut Tahrir, Majelis Mujahidin, Ansharut Tauhid, Islam Tradisional, Majelis Tafsir al-Qur'an, dan kelompok Shyi'ah.

Konsep Jihad Kedua, memberikan pandangan Kebangsaan dan kemanusiaan. Muhammadiyah memahami bahwa Islam memiliki pandangan tentang masyarakat yang dicita-citakan, yakni masyarakat Islam yang sebenar-benarnya. Dalam pesan Al- Quran (QS. Ali Imran ayat 110; Al Baqarah ayat 143), masyarakat Islam yang diidealisasikan merupakan perwujudan khaira ummah (umat terbaik) yang memiliki posisi dan peran ummatan wasatha (umat tengahan), dan syuhada 'ala al-nas (pelaku sejarah) dalam kehidupan manusia. Masyarakat Islam adalah suatu masyarakat yang di dalamnya ajaran Islam berlaku dan menjiwai seluruh bidang kehidupan yang dicirikan oleh ber-Tuhan dan beragama, berpersaudaraan, berakhlak dan beradab, berhukum syar'i, berkesejahteraan, bermusyawarah, berihsan, berkemajuan, berkepemimpinan, dan berketertiban. Dengan demikian masyarakat Islam menampilkan corak yang bersifat tengahan, yang melahirkan format kebudayaan dan peradaban yang berkeseimbangan.

Konsep jihad ketiga, muhammadiyah berkomitmen mengadakan pencerahan (tanwir) Gerakan pencerahan menampilkan Islam untuk menjawab masalah kekeringan ruhani, krisis moral, kekerasan, terorisme, konflik, korupsi, kerusakan ekologis, dan bentuk-bentuk kejahatan kemanusiaan. Gerakan pencerahan berkomitmen untuk mengembangkan relasi sosial yang berkeadilan tanpa diskriminasi, memuliakan martabat manusia laki-laki dan perempuan, menjunjung tinggi toleransi dan kemajemukan, dan membangun pranata sosial yang utama.

Untuk mewujudkan konsep tersebut, ada enam nilai dasar yang dibangun dalam dakwah Muhammadiyah. Pertama, pendidikan Muhammadiyah diselenggarakan merujuk pada nilai-nilai yang bersumber pada al-Qur'an dan Sunnah. Kedua, ruh al-ikhlas untuk mencari rida Allah menjadi dasar dan inspirasi dalam ikhtiar

19 Haedar Nashir, Memahami Ideologi Muhammadiyah (Yogyakarta: Suara Muhammadiyah, 2015), 61-62 
mendirikan dan menjalankan amal usaha di bidang pendidikan. Ketiga, menerapakan prinsip kerjasama (musharakah) dengan tetap memelihara sikap kritis, baik pada masa Hindia Belanda, Dai Nippon (Jepang), Orde Lama, Orde Baru hingga pasca Orde Baru. Keempat, selalu memelihara dan menghidup-hidupkan prinsip pembaruan (tajdid), inovasi dalam menjalankan amal usaha di bidang pendidikan. Kelima, memiliki kultur untuk memihak kepada kaum yang mengalami kesengsaraan du'afa dan mustad'afîn dengan melakukan proses-proses kreatif sesuai dengan tantangan dan perkembangan yang terjadi pada masyarakat Indonesia. Keenam, memerhatikan dan menjalankan prinsip keseimbangan (tawassut atau moderat) dalam mengelola lembaga pendidikan antara akal sehat dan kesucian hati. ${ }^{20}$

Sedangkan Jihad menurut kalangan Nadliyin diartikan sebagi salah satu kesungguhan dalam menyembah allah SWT. Belajar degan sungguh-sungguh dipandang sebagai jihad karena kesungguhan dan keseriusan di dalamnya, bukan karena belajarnya. NU selalu mengutamakan pendekatan spiritual untuk menumbuhkan kesadaran yang mampu mendorong transformasi individual maupun sosial. Hal ini didasari kenyataan bahwa ketegangan batiniah antara roh dan hawa nafsu berdampak pada aktivitas lahiriah. Bahkan, ketegangan batiniah ini kerap memicu konflik-konflik lahiriah, baik antar individu maupun sosial. Dalam konteks inilah, sabda Nabi Muhammad saw. kepada para sahabat, "Raja'na min jihad al-ashghar ila jihad al-akbar" (Kita pulang dari jihad kecil menuju jihad besar), ${ }^{21}$ sepulang dari perang Badr me-

\footnotetext{
20 Ibid., 130-131.

${ }^{21}$ Hadits ini sangat populer di antara para ulama tradisional dan para sufi, namun dianggap lemah (dla'if) oleh beberapa pihak dan ditolak oleh sekte Wahabi. Secara riwayah hadits ini memang dinilai lemah. Tapi secara dirayah, hadits ini konsisten dengan pesan utama jihad dalam Islam. Ini bisa dilihat dalam hadits lain sekalipun dengan redaksi berbeda namun secara ma'nawi sejalan dengan maksud hadits di atas, seperti riwayat Ahmad ibn Hanbal, dalam hadits nomor 24678, 4692, dan 24465, "Al-Mujahid man jahada nafsahu li-Llah atau fi Allah 'azz wa jall" (Mujahid adalah orang yang berjihad terhadap dirinya demi Allah, atau dalam riwayat lain dalam ('jalan menuju') Allah Yang Maha mulia dan Maha Agung). Baca dalam: Abu 'Abdillah Ahmad ibn Muhammad ibn Hanbal, Masnad Ahmad, (Cairo: Mauqi' Wizarat al-Auqaf al-Mishriyyah, tt.). Bisa dilihat juga hadits yang dikemukakan dalam Fath al-Qadir karya alSyaukani,"Al-Mujahid man jahada nafsah fi tha'at Allah" (Mujahid adalah orang yang berjihad terhadap dirinya dalam ketaatan kepada Allah), diriwayatkan oleh Ibn Jarir, dan al-Hakim meyakininya shahih, diriwayatkan pula oleh Ibn Mardawaih dari 'Aisyah al-Syukani, Fath alQadir (Cairo: Mauqi' al-Tafasir, tt.), Vol. 5, h. 142. Hal penting yang perlu ditekankan adalah bahwa jihad lebih menekankan pada usaha sungguh-sungguh untuk mengendalikan diri, mengendalikan hawa nafsu. Al-Razy misalnya bahkan menekankan bahwa jihad dalam konteks perang (qital) pun harus diawali dengan kemenangan pertama dan terutama terhadap diri sendiri, seperti tidak munafik, tidak riya', dan tidak untuk kepentingan sendiri. Semua harus
} 
njadi sangat penting untuk direnungkan. Mendengar pernyataan tersebut, para sahabat sangat terkejut. Mereka bertanya-tanya, perang (qital) apa lagi yang lebih dahsyat. Rasulullah saw. menjelaskan, "Perang melawan hawa nafsu." Para sahabat terdiam, sadar betapa berat dan sulit melawan musuh di dalam diri. Selain sulit diidentifikasi, melawan musuh dalam selimut juga menuntut ketegasan dan ketegaran emosional karena ia merupakan bagian tak terpisahkan dari diri setiap orang.

Hawa nafsu adalah suatu kekuatan yang selalu menyimpan potensi destruktif dan membuat jiwa selalu resah, gelisah, dan tidak pernah tenang. Para ulama kerap membandingkan hawa nafsu dengan binatang liar. Siapa pun yang telah menjinakkan hawa nafsunya, dia akan tenang dan mampu menggunakan nafsunya untuk melakukan aktivitas dan/atau mencapai tujuan-tujuan luhur. Sebaliknya, siapa pun yang masih dikuasai hawa nafsunya, dia akan selalu gelisah dan ditunggangi oleh hawa nafsunya, dia membahayakan dirinya dan orang lain. ${ }^{22}$

Dari perspektif ini ada dua kategori manusia: Pertama, orang-orang yang sudah mampu menjinakkan hawa nafsunya sehingga bisa memberi manfaat kepada siapapun. Mereka adalah pribadi-pribadi yang tenang dan damai (al-nafs al-muthmainnah) dan menjadi representasi kehadiran spiritualitas, khalifat Allah yang sebenarnya. ${ }^{23}$

Kedua, mereka yang masih dikuasai hawa nafsu sehingga selalu menjadi biang keresahan dan masalah bagi siapa pun. Mereka adalah pribadi-pribadi gelisah dan menjadi biang kegelisahan sosial dan pembuat masalah (al-nafs al-lawwamah) dan menjadi representasi kehadiran hawa nafsu, orang-orang musyrik ${ }^{24}$ yang sebenarnya.

Sikap moderat NU nampak dalam pandangan-pandangan politiknya. Tiga prinsip yang sering dijadikan dasar pengambilan keputusan politik NU adalah kebijaksanaan, keluwesan, dan

dilakukan secara ikhlas yang berarti harus diawali dengan usaha mengendalikan diri agar aktivitas apa pun yang akan dilakukan tidak dikendalikan oleh hawa nafsu (baca dalam: Fakhruddin al-Razi, Mafatih al-Ghaib (Cairo: Mauqi' al-Tafasir, tt.), vol. 7, h. 474). Kesimpulannya, hadits Raja'na min jihad al-ashghar ila jihad al-akbar diterima oleh para ulama tradisional dan para sufi karena secara dirayah sejalan dengan hadits-hadits lain yang secara riwayah berada dalam kualitas shahih.

22 The Wahid Institute, Ilusi Negara Islam..., h. 13

23 Ibid., h. 13

24 "Para ahli tafsir mengatakan, orang musyrik ialah orang yang melakukan ibadah, atau melakukan amal shaleh tidak li-llah, tidak karena Allah. Jadi, wa am yusyrik bi 'ibadati Rabbihi ahada (dan tidak menyekutukan apa pun dalam ibadah kepada Tuhannya). Jadi dia melakukan sesuatu misalnya, dia berjuang katanya misalnya untuk Islam, tapi sebetulnya untuk kepentingan dirinya sendiri, itu sebetulnya sudah menyekutukan tuhan." 
moderatisme. Tradisi memilih jalan damai dalam wacana politik NU umumnya melalui prinsip-prinsip yurisprudensi dan kaidah-kaidah yang menganjurkan minimalisasi risiko, pengutamaan asas manfaat, dan menghindari hal-hal yang ekstrem.

Bangunan moderatisme teologis NU ditopang oleh "trilogi" ajaran: Pertama: al-tawassuth atau sikap tengah-tengah, sedang-sedang, tidak ekstrim kiri ataupun ekstrim kanan. Sikap ini diderivasi dari ayat alQur'an (Al-Baqarah: 143):

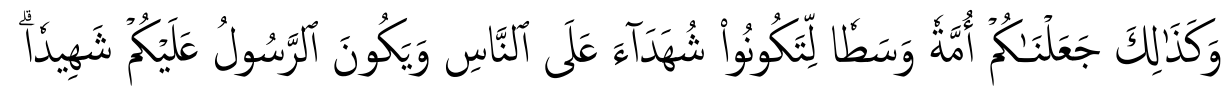

Artinya: "Dan demikian (pula) Kami telah menjadikan kamu (umat Islam), umat yang adil dan pilihan agar kamu menjadi saksi atas (perbuatan) manusia dan agar Rasul (Muhammad) menjadi saksi atas (perbuatan) kamu..."

Kedua: i'tidal tegak lurus. sikap adil dalam menyikapi suatu persoalan. Adil adalah sikap proporsional dalam menyikapi persoalan berdasarkan hak dan kewajiban. Ibarat NU adalah kereta, sebagai penumpang, jangan membawa NU menuruti kemauan penumpang, tetapi penumpang harus mengikuti sopirnya, selain itu, Warga Nahdliyin dalam mensikapi berbagai macam harus berani mengatakan yg haq itu adalah haq, dan yang bathil itu adalah bathil walaupun terhadap org lain yg berbeda agama, ras, suku dan kebangsaannya. konsep al-i'tidal diderivasi dari QS al-Ma'idah: 8

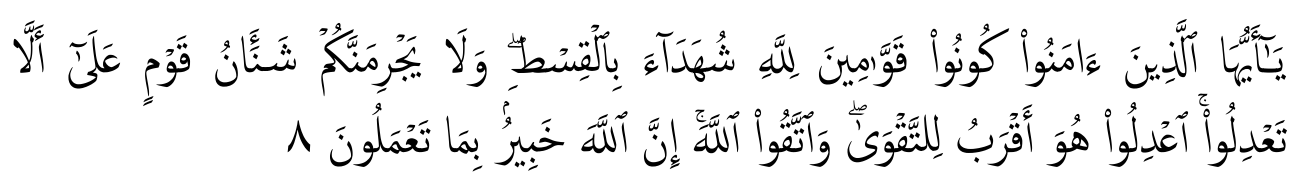

Artinya: "Hai orang-orang yang beriman hendaklah kamu jadi orang-orang yang selalu menegakkan (kebenaran) karena Allah, menjadi saksi dengan adil. Dan janganlah sekali-kali kebencianmu terhadap sesuatu kaum, mendorong kamu untuk berlaku tidak adil. Berlaku adillah, karena adil itu lebih dekat kepada takwa. Dan bertakwalah kepada Allah, sesungguhnya Allah Maha Mengetahui apa yang kamu kerjakan."

Ketiga; al-tawazun atau seimbang dalam segala hal, terrnasuk dalam penggunaan dalil 'aqli (dalil yang bersumber dari akal pikiran rasional) dan dalil naqli (bersumber dari Alquran dan Hadis) Artinya Warga Nahdliyin dalam mensikapi berbagai macam persoalan disikapinya dg pola yg terukur, terarah, terkonsep dan dan tersusun 
dengan metodologi yg bisa dipertanggung jawabkan. konsep altawazun diambil dari QS al-Hadid: 25

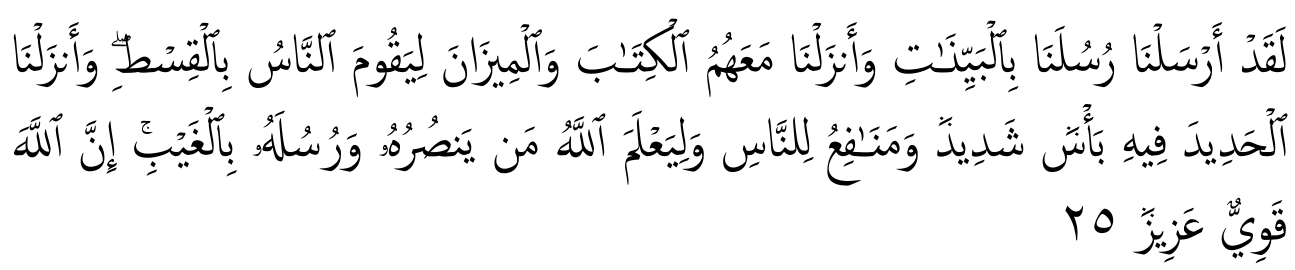

Artinya: "Sesungguhnya Kami telah mengutus rasul-rasul Kami dengan membawa bukti-bukti yang nyata dan telah Kami turunkan bersama mereka Al Kitab dan neraca (keadilan) supaya manusia dapat melaksanakan keadilan". Dan Kami ciptakan besi yang padanya terdapat kekuatan yang hebat dan berbagai manfaat bagi manusia, (supaya mereka mempergunakan besi itu) dan supaya Allah mengetahui siapa yang menolong (agama)Nya dan rasul-rasul-Nya padahal Allah tidak dilihatnya. Sesungguhnya Allah Maha Kuat lagi Maha Perkasa".

Manifestasi ketiga prinsip dan karakter di atas, menurut sejumlah ulama NU, harus ditampakkan pada seluruh bidang ajaran Islam seperti bidang akidah, shari'ah, tasawwuf dan akhlak, bidang mu'asharah (pergaulan sosial), bidang kehidupan bernegara-bangsa, bidang kebudayaan, bidang dakwah, dan bidang-bidang lain. ${ }^{25}$

\section{2) Dialektika Kontruksi Sosial Konsep Jihad PDM dan PCNU Kota Madiun}

Dalam teori konstruksi sosial terdapat proses dialektika antara dunia subjektif dan dunia objektif. Dari proses dialektika tersebut muncul berbagai varian konstruksi sosial tentang dunia atau wacana yang konstruk. Dalam pembahasan ini akan dijelaskan tiga proses konstruksi sosial menurut teori Berger, yaitu eksternalisasi, objektivasi dan internalisasi.

Melalui pembacaan teori Berger ini akan diperoleh deskripsi, pemahaman dan pandangan seseorang atau sekelompok orang atau golongan tentang dunia yang dipersepsi. Di antara persoalan yang digali dan dipaparkan dalam pembahasan ini adalah mengenai makna jihad oleh masing-masing Ormas Muhammadiyah dan Nahdlotul Ulama'.

Di bawah ini dijelaskan secara rinci proses dialektika terkait dengan konstruksi sosial Konsep Jihad PDM dan PCNU Kota Madiun

25 Masdar Hilmy, Ekslempar Moderatisme Indonesia; Refleksi dan Retrospeksi atas Moderatisme NU dan Muhammadiyah. Kompas.com. 2012, h. 7 
melalui tiga momen simultan (eksternalisasi, objektivitas dan internalisasi):

Mengikuti konstruksi sosial Berger, realitas sosial jihad menjadi teperlihara dengan terbahasakannya dalam Al-Quran, hadits, bukubuku/ manuskrip ulama yang terpelihara hingga kini. Agama (Islam) berhasil melegitimasikan jihad, terlebih dengan menjadikan agama sebagai ideologi negara. Alhasil, bersatunya dua kekuatan besar (agama dan negara) selama berabad-abad (selama imperium Islam) menjadikan jihad sebagai realitas sosial yang tak terbantahkan, bahkan mustahil untuk dihilangkan.

Sosialisasi jihad terus berlangsung seiring sosialisasi Islam. Jihad terus diinternalisasi oleh individu muslim, sehingga menjadi realitas subyektif. Realitas subyektif itu terus dieksternalisasikan dalam kehidupan sehari-hari. Karena jihad memiliki makna yang luas, sehingga dapat dieksternalisasikan dalam setiap detik dan ruang kehidupan kaum muslim. Jihad mengisi keseharian rakyat Palestina. yang mengangkat senjata melawan Israel, menjadi titik tolak muslimin Irak mengusir Amerika dan sekutunya, menjadi jalan muslimin Amerika menyebarkan Islam rahmatan lil-'alamiin. Jihad juga menjadi ruh dakwah mubaligh-mubaligh Muhammadiyah dan kyai-kyai NU.

Jihad adalah sahabat umat Islam saat menunaikan sholat, puasa, dan haji, saat bekerja menghidupi keluarga, saat membantu mengentaskan rakyat miskin, dan saat mengkhidmatkan dirinya dalam ibadah, dimana pun dan kapan pun. Jihad memiliki kenyataan obyektif yang tak bisa dinihilkan. Namun di sisi lain, jihad adalah kenyataan subyektif yang relatif, plural, dan dinamis. Jihad qital bisa menjadi nyata bagi sebagian orang, tapi bisa tidak menjadi 'nyata' bagi sebagian yang lain. Jihad memiliki keragaman makna (subyektif), tiap individu memiliki penafsiran sendiri-sendiri, dan penafsiran (makna subyektif) itu terus berproses dan memungkinkan untuk berubah.

Muhammadiyah dalam membahas persoalan hukum baru yang mengemuka, selalu mencari jawabannya dalam al-Qur'an dan Sunnah. Jika tidak ditemukan jawabannya secara langsung dalam al-Qur'an dan Sunnah, Majlis Tarjih menggunakan ijtihad dengan istinbath dari nash (teks) yang ada melalui persamaan 'illat (alasan hukum). Dengan demikian, kendati qiyas (analogi) tidak diakui secara langsung, namun dalam prakteknya tetap dikembangkan Muhammadiyah dalam menetapkan hukum. Sedangkan ijma', Muhammadiyah hanya menerima ijma' al-shahabah (kesepakatan sahabat) yang mengikuti pandangan Ahmad bin Hanbal, yang berarti bahwa ijma' tak mungkin terjadi pasca generasi sahabat Rasulullah (Khulafa'ur Rasyidin). Dalam 
praktiknya Muhammadiyah tidak dapat melepaskan diri dari pemikiran mazhab, meskipun hanya pada tingkat metode atau yang akrab disebut mazhab manhaji.

Dalam membendung laju radikalisme agama tersebut Muhammadiyah tidak pernah melakukan pembendungan secara riil akan tetapi lebih mengetatkan di intern warga Muhammadiyah seperti berdakwah yang dikemas dalam amaliyah Sehingga dari sini anggota atau simpatisan Muhammadiyah ketika diajak pada prilaku radikal bisa mencegah untuk tidak terlibat didalamnya.

Dalam menginternalisasikan konsep jihadnya kepada jamaahnya, Muhammadiyah lebih mengedepannkan aksinya yaitu berupa pendidikan, pesantren, rumah sakit, panti asuhan, buku, amal usaha dan lain sebagainya.

\section{Gambar 2:}

\section{Dialektika Kontruksi Sosial Konsep Jihad PDM Kota Madiun}

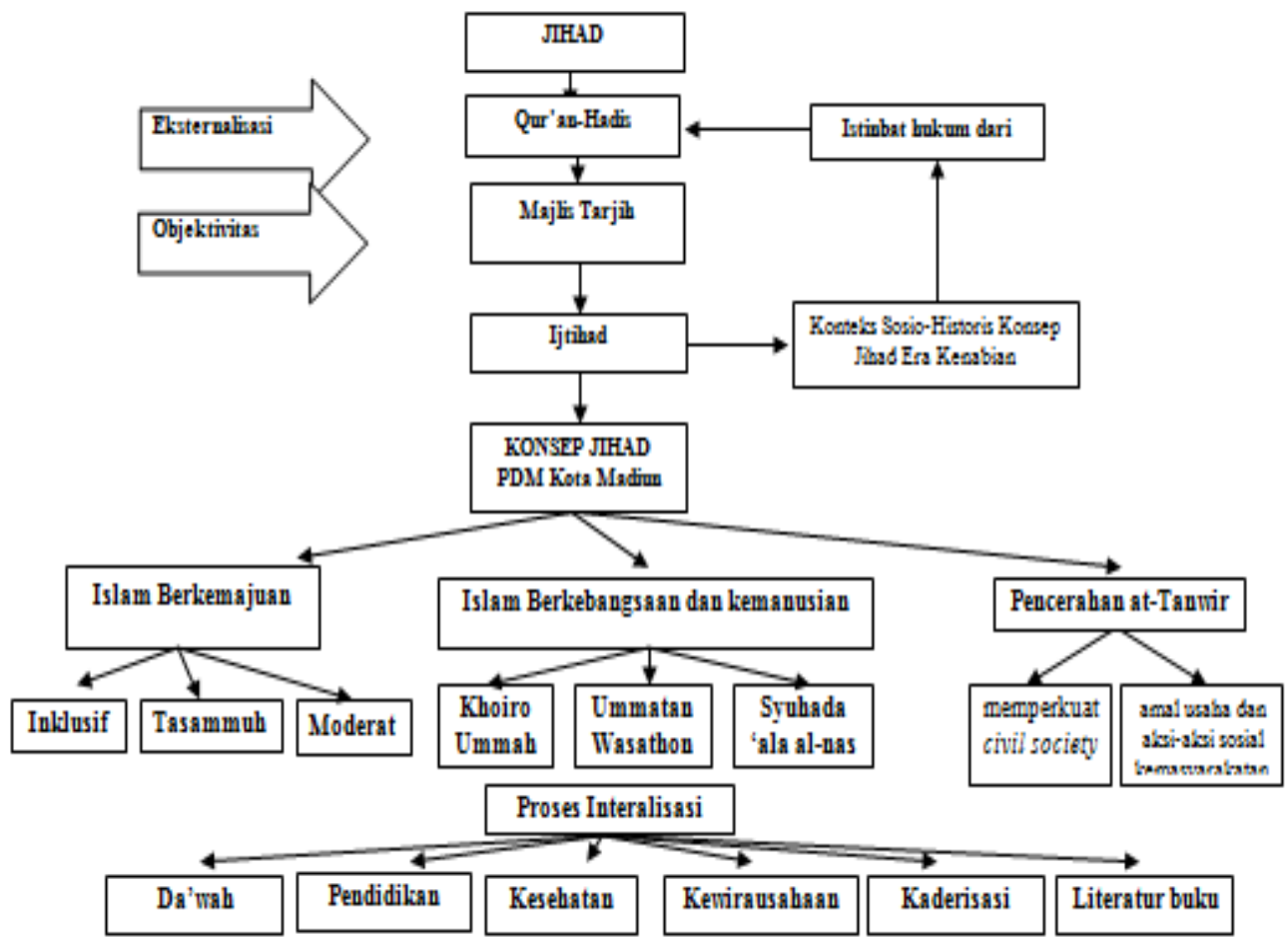

Disamping Muhammadiyah, Nahdhatul Ulama (NU) mempunyai tanggungjawab moral untuk berpartisipasi memberikan solusi atas persoalan-persoalan sosial keagamaan yang tengah dihadapi oleh masyarakat khususnya warga nahdhiyyin. Guna keperluan itulah, NU 
membentuk lembaga yang disebut dengan Lajnah Bahtsul Masail atau yang disingkat LBM. Yakni, suatu lembaga yang bertugas menjawab segala permasalahan sosial keagamaan yang dihadapi masyarakat.

Dalam akar sejarahnya NU mengambil Manhaj Aswaja dalam menjalankan organisasinya. Bagaimana manhaj aswaja yang diterapkan oleh NU itu, bahwa ada tokoh-tokoh ulama' klasik yang dijadikan pedoman ketika memutuskan sesuatu. Misalnya dalam bidang sufi NU merujuk pada Abu Junaid al-Baghdadi dan Imam Al-Ghozali. Bidang akidah dan tauhid, NU merujuk paada Abu Mansur al-Maturidi dan Abu Hasan al-Asy'ari, dalam bidang Fiqh, NU merujuk pada 4 madzhab yang berkembang saat ini yaitu Imam Syafi'i, Imam Malik, Imam Hanafi dan Imam Hanbali.

Proses dialektika kontruksi sosial konsepsi jihad PCNU Kota Madiun adalah pada tahap pertama ekternalisasi, NU memaknai jihad dengan merujuk pemaknaan pada teks-teks Al-Qur'an dan hadis, selanjutnya mencari konteks sosio-historis konsep jihad Era Kenabian dan kemudian mencari referensi konsep jihad dalam literatur fiqih klasik dan Modern serta mengambil istinbat / kesimpulan dari hasil bahsul masail tersebut menjadi sebuah konsep jihad yang terdiri dari 4 macam yaitu : at-tawasuth, at-tawazun, i'tidal dan tasammuh.

Selanjutnya untuk menginternalisasikan keemapt konsep jihad sebagai upaya membendung laju radikalisme agama di Indonesia adalah dengan upaya : Pertama, dakwah, cakupan dakwah NU sudah tersebar luas dan banyak diikuti oleh masayarakat, salah satunya adalah muslimat, Tahlil, dzikir, Fida', pengajian, JQH dll. Kedua, pendidikan. Banyak pesantren dan pendidikan yangsudah didirikan oleh NU, proses internalisasi ini bisa tercapai dengan mengajarkan pendidikan anti radikalisme agama kepada siswa, Ketiga, Kaderisasi. IPNU, IPPNU, Anshor dll, Keempat, kewirausahaan. 


\section{Gambar 3:}

\section{Dialektika Kontruksi Sosial Konsep Jihad PCNU Kota Madiun}

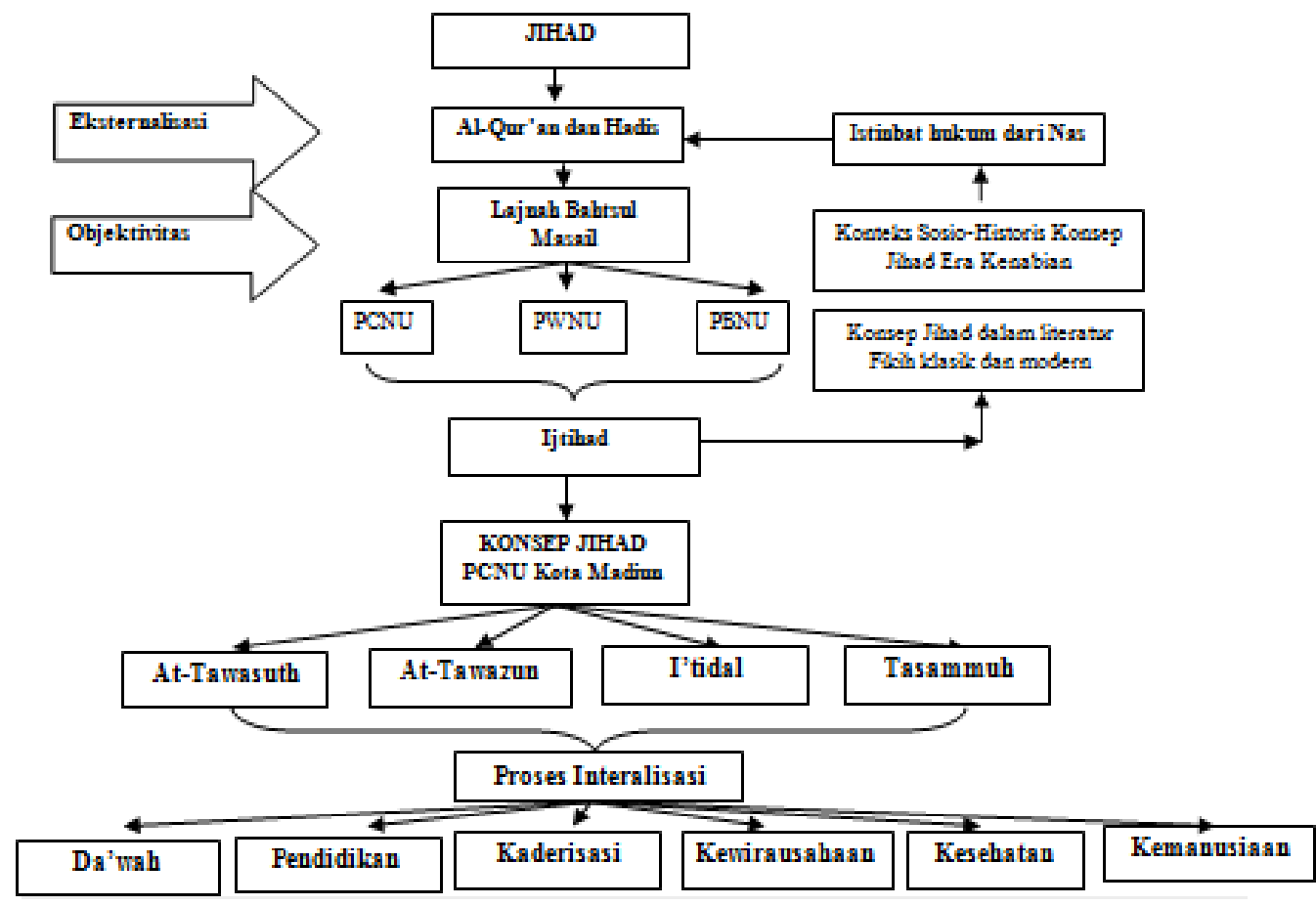

\section{E. Penutup}

Pada dasarnya konsep jihad yang diusung oleh dua organisasi Islam terbesar di Indonesia serupa, karena keduanya memiliki sikap moderat, mau berdialog, menghormati golongan lain, tidak menyatakan bahwa dirinya atau golongannyalah yang paling benar dalam berpaham, sehingga tidak terjebak pada ekstimitas yang berlebihan.

Muhammadiyah lebih memaknai jihad dengan dakwah amaliyah yang sedang dibutuhkan oleh ummat seperti membangun rumah sakit, sekolah, panti asuhan, pesantren, dan lain sebaginya, sebagaimana selogan Muhammadiyah "Hidup hidupilah Muhammadiyah dan jangan mencari kehidupan di Muhammadiyah". Dakwah amaliyah tersebut sesuai dengan konsep jihadnya yaitu: a). Islam berkemajuan, mengusung tema inklusif, tasammuh, dan moderat, b) Islam berkebangsaan dan berkemajuan, mengusung tema Khoiro ummah, Ummatan wasathon, Syuhada' al-nas, c) Pencerahan/at-Tanwir yang mengusung tema memperkuat civil society denga amal usaha dan aksi-aksi sosial kemasyarakatan.

Sedangkan Nahdlutul ulama dalam memaknai jihad lebih ditekankan pada perang melawan hawa nafsu karena hawa nafsu merupakan suatu 
kekuatan yang selalu menyimpan potensi destruktif dan membuat jiwa selalu resah, gelisah, dan tidak pernah tenang. Oleh karena itu jihad dalam melawan hawa nasu diwajibkan sebagai wasilah terciptanya ummatan wasathon yang selalu menjaga ukhuwah islamiyah, ukhuwah basyariyah dan ukhuwah wathoniyah. Dalam menjaga ukhuwah islamiyah tersebut NU mengajarkan konsep jihad yang menjadi karakter dasar NU yaitu: tawassuth, i'tidal, tawazun, tasammuh, amar makruf nahi munkar berdasarkan al-Quran dan alHadits dengan pendekatan bermadzhab, dasar-dasar akhlak khas NU, sikap kemasyarakatan, kebangsaan dan kenegaraan NU, sikap terhadap ulama dan keulamaan, dan lainnya.

\section{Daftar Pustaka}

Amstrong, Karen. 2001. Berperang Demi Tuhan, terj.Sutrisno Wahono dkk,. Jakarta Bandung: Kerjasama Serambi dengan Mizan.

Azra, Azyumardi Akar Radikalisme Keagamaan Peran Aparat Negara, Pemimpin Agama dan Guru untuk Kerukunan Umat Beragama (Makalah dalam Workshop "Memperkuat Toleransi Melaluai Institusi Sekolah", yang diselenggarakan oleh The Habibie Center, 14 Mei 2011, di Hotel Aston Bogor), dan dikutip oleh Abdul Munip, Menangkal Rdikalisme di Sekolah. Jurnal Pendidikan Islam UIN Sunan Kalijaga Program Pasca Sarjana No 2 Vol 1, Desember 2012.

Berger, Peter L. \& Thomas Lukhmann. 1190. Tafsir Sosial atas Kenyataan.. Jakarta: LP3ES.

Departemen Pendidikan dan Kebudayaan, 1990. Kamus Besar Bahasa Indonesia. Jakarta: Balai Pustaka.

Hasani, Ismail dan Bonar Tigor Naipospos, 2010. Radikalisme Agama di Jabodetabek \& Jawa Barat: Implikasinya terhadap Jaminan Kebebasan Beragama/Berkeyakinan. Jakarta: Pustaka Masyarakat Setara.

Hilmy, Masdar. 2012. Ekslempar Moderatisme Indonesia; Refleksi dan Retrospeksi atas Moderatisme NU dan Muhammadiyah. Kompas.com.

Hornby A.S., 2000. Oxford Advenced, Dictionary of current English. UK: Oxford university press.

Kartodirdjo, Sartono. 1985. Ratu Adil. Jakarta: Sinar Harapan.

Lampiran Laporan Pimpinan Pusat Muhammadiyah, "Laporan Lembaga Pimpinan Pusat Muhammadiyah Periode 2010-2015", diterbitkan oleh Pimpinan Pusat Muhammadiyah, 2015. 
JURNAL PIWULANG, Vol. I No. 1 September 2018, 33-53

Malcoln, Water. 1994. Modern Sosiological Theory. London: Sage Publications.

Manzur,Ibn. t.t. Lisan al-'Arab. Kairo: Dar al-Ma'arif.

Masduqi, Irwan. Deradikalisasi Pendidikan Islam Berbasis Khazanah Pesantren. Jurnal Pendidikan Islam, No 2 Vol 1, 2012.

Moleong, Lexi J. 1992. Metodologi Penelitian Kualitatif. Bandung : Remaja Rosdakarya.

Nashir, Haedar. 2015. Dinamisasi Gerakan Muhammadiyah, Agenda Strategis Abad Kedua. Yogyakarta: Suara Muhammadiyah.

2015. Memahami Ideologi Muhammadiyah. Yogyakarta: Suara Muhammadiyah.

Nuhrison M. Nuh, 2009. Faktor-Faktor Penyebab Munculnya Faham/Gerakan Islam Radikal di Indonesi. HARMONI Jurnal Multikultural \& Multireligius, Vol VIII Juli-September.

Rohmanu, Abid "Kritik Teks dan Kekerasan Atas Nama Agama", al-Adabiya, Vol. 2, No. 1. Januari-Juni 2007.

Shihab, Alwi. 1998. Islam Inklusif. Jakarta: Mizan.

Wahid, Abdurrahman 2009. Musuh dalam Selimut. Dalam Buku Ilusi negara Islam : ekspansi gerakan Islam transnasional di Indonesia. Jakarta : TheWahid Institute. 